\title{
RASA SYUKUR KAITANNYA DENGAN KESEJAHTERAAN PSIKOLOGIS PADA GURU HONORER SEKOLAH DASAR
}

\author{
Asti Aisyah dan Rohmatun Chisol \\ Fakultas Psikologi Universitas Islam Sultan Agung, Jl. Kaligawe Raya km 4 Semarang \\ Email: rohmatun@unissula.ac.id
}

\begin{abstract}
Abstrak
Penelitian ini bertujuan untuk menguji hubungan antara rasa syukur berhubungan dengan kesejahteraan Psikologis pada guru honorer honorer sekolah dasar di UPT Disdikpora Kecamatan Pecangaan Kabupaten Jepara. Subjek berjumlah 63 guru. Tehnik pengambilan data dengan menggunakan insidental sampling. Metode pengumpumplan data dengan menggunakan Skala kesejahteraan psikologis dan skala rasa syukur. Adapun analisis data dengan menggunakan tehnik korelasi Product Moment, dan diperoleh nilai $r_{x y}=0,744$ dengan signifikansi $0.000(p<0.01)$, hal ini menunjukkan bahwa ada hubungan positif yang siginifikan antara rasa syukur dengan kesejahteraan psikologis pada guru honorer sekolah dasar. Sumbangan efektif yang diberikan rasa syukur terhadap kesejahteraan psikologis adalah sebesar $55,4 \%$, adapun yang $44,6 \%$ dipengaruhi oleh faktor lain yang tidak disertakan dalam penelitian ini, diantaranya usia, jenis kelamin, kepribadian, status sosial, religiusitas dan dukungan social
\end{abstract}

Kata kunci : Kesejahteraan Psikologis, Rasa Syukur

\section{GRATITUDE IN RELATION WITH PSYCHOLOGICAL WELL BEING AMONG HONORARY TEACHER IN ELEMENTARY SCHOOL}

\begin{abstract}
This study aims to examine the relationship between gratitude related to psychological well-being in honorary elementary school teachers in the UPT Disdikpora Pecangaan District, Jepara Regency. Subjects totaled 63 teachers. Techniques for retrieving data using incidental sampling. Data collection method using a scale of psychological well-being and a scale of gratitude. The data analysis using Product Moment correlation technique, and obtained the value of rxy $=0.744$ with a significance of $0.000(p<0.01)$, this shows that there is a significant positive relationship between gratitude and psychological well-being in elementary school honorary teachers. Effective donations given gratitude for psychological well-being amounted to $55.4 \%$, while $44.6 \%$ were influenced by other factors not included in this study, including age, gender, personality, social status, religiosity and social support.
\end{abstract}

Key word: Psychological well-being, gratitude

\section{PENDAHULUAN}

Perkembangan kepribadian manusia banyak dipengaruhi oleh banyak hal, salah satu factor yang sangat penting dalam perkembangan kepribadian manusia adalah pendidikan. Berbeda dengan bidang yang lainnya, bidang pendidikan lebih berhubungan secara langsung dalam pembentukan kepribadian manusia, hal ini dikarenakan pendidikan turut menentukan model manusia yang kelak akan dihasilkan. Upaya mengembangkan pendidik dalam pembangunan pendidikan merupakan hal yang harus dilakukan karena dengan demikian pendidik dapat mengembangkan dirinya untuk mengembangkan sumber daya manusia serta tatanan kehidupan. Berdasarkan Undang-Undang Dasar 1945 upaya untuk mencerdaskan kehidupan bangsa dan mengembangkan kualitas manusia menjadi tanggung jawab professional setiap guru. 
110

Guru merupakan salah satu bagian terpenting dalam pendidikan. Selain itu, guru juga berperan penting dalam pembentukan kualitas dan kuantitas pembelajaran. Berdasarkan UU RI Nomor 14 Tahun 2005 tentang guru, Pasal 1 ayat 2, yang berbunyi bahwa: guru adalah pendidik profesional dengan tugas utama mendidik, mengajar, membimbing mengarahkan, melatih, menilai, serta mengevaluasi peserta didik pada pendidikan usia dini jalur pendidikan formal, pendidikan dasar, dan pendidikan menengah. Guru berperan sebagai pembimbing dalam melaksanakan belajar mengajar. Menyediakan keadaan-keadaan yang memungkinkan peserta didik merasa nyaman dan yakin bahwa percakapan dan prestasi yang mencapai akan mendapatkan penghargaan dan perhatian sehingga dapat meningkatkan motivasi berprestasi peserta didiknya (UU RI, 2005)

Pengelompokan guru di sekolah yang berstatus negeri ada dua, yaitu guru tetap yang bestatus pegawai negeri sipil (PNS) dan guru honorer yang dikenal dengan sebutan guru wiyata bakti atau guru tidak tetap (GTT). Menurut Peraturan pemerintah Nomor 48 Tahun 2005 tentang Pengangkatan Tenaga Kerja Honorer menjadi CPNS dijelaskan bahwa tenaga guru honorer adalah seseorang yang diangkat oleh pejabat Pembina kepegawaian atau pejabat lain dalam pemerintah untuk melaksanakan tugas tertentu pada instansi pemerintah atau yang penghasilannya menjadi beban APBN/APBD. Tugas guru PNS dan guru honorer yaitu melaksanakan pembelajaran dan menyusun administrasi, tetapi mereka mempunyai perbedaan pendapatan karena guru PNS gajinya dijamin oleh pemerintah dan guru honorer gajinya dari biaya operasional sekolah karena guru PNS diangkat oleh pemerintah dan guru honorer SK pengangkatannya dari komite sekolah (Suyanto \& Abbas, 2005).

Kebutuhan sehari-hari dan kebutuhan mengaktualisasikan diri telah menyebabkan konsentrasi guru honorer terpecah antara tugas sebagai seorang guru honorer yanh diharuskan meningkatkan kemampuan kapasitas akademis pembelajaran dengan terus mempengaruhi dan melakukan inovasi dengan media yang tersedia, memperbaharui metode pembelajaran, dan juga meningkatkan kapasitas dirinya, selain itu ia juga diharuskan untuk memenuhi kebutuhan hidup dengan melakukan usaha atau kegiatan lain. Hal ini menyebabkan guru honorer harus berusaha untuk memenuhi kebutuhan hidupnya untuk mencapai kesejahteraan. Pemenuhan kebutuhan tersebut berkaitan dengan kesejahteraan psikologis seseorang, yang mana semakin terpenuhinya kebutuhan tersebut, maka kesejahteraan psikologisnya akan mengalami peningkatan, sehingga, uang yang dianggap sebagai alat untuk meningkatkan akses guna memperoleh kesenangan dan merealisasikan diri untuk mencapai kesejahteraan psikologis (Ryan \& Deci, 2001)

Persoalan guru honorer di Kabupaten Jepara tak kunjung usai, (dalam koran muria pada sabtu tangal 29 april 2016), kali ini forum komunitas guru tidak tetap (FK-GTT) Jepara 'menggeruduk' kantor Dewan Perwakilan Daerah (DPRD) untuk audiensi. Dalam audiensi mereka menyampaikan sejumlah tuntutan, salah satunya adalah permintaan gaji yang setara dengan upah minimum kabupaten (UMK) Jepara. Ketua FK-GTT menyampaikan sampai saat ini masih terdapat ribuan guru tidak tetap masuk daftar guru honorer di Kabupaten Jepara. Selama ini guru honorer mendapatkan gaji yang jauh dari kata layak. Sebulan rata-rata hanya menerima gaji Rp 200 ribu, bahkan ada yang gajinya Rp 100 ribu. Karena itu, ia meminta gaji honorer setara dengan UMK. Kemudian, aturan pemberian upah tersebut dituangkan kedalam peraturan bupati (Zaman, 2016)

Kesejahteraan psikologis menurut (Ryff C. D., 1989) merupakan kondisi pada saat individu mampu menerima kelebihan serta kekurangan yang dimiliknya, mempunyai tujuan hidup yang jelas, menjadi pribadi yang mampu mandiri, mampu membina serta mengembangkan hubungan yang positif dengan orang lain, dan mempunyai kemampuan untuk mengendalikan lingkungannya serta terus 
berkembang secara persona. Kesejahteraan psikologis sebagai kehidupan yang berjalan baik, berkombinasi dengan perasaan yang sejahtera serta berfungsi secara efektif. Individu yang memiliki kesejahteraan psikologis tinggi merasa mampu, mendapatkan dukungan, puas dengan kehidupan dan mempunyai perasaan yang bahagia (Hamburger, 2009).

Kesejahteraan psikologis menurut Aspinwall (Ramadhani, Djunaidi, Sismiati, 2016), menggambarkn bagaimana psikologis individu dapat berfungsi dengan baik dan juga positif. Schultz (Ramadhani, Djunaidi, Sismiati, 2016), menjelaskan bahwa kesejahteraan psikologis sebagai fungsi positif pada diri individu, dimana fungsi positif tersebut merupakan arah dan tujuan yang harus diusahakan oleh individu yang sehat untuk segera dicapai. Kesejahteraan psikologis menurut (Ryff C. D., 1989) bukan hanya terdiri dari efek positif, negatif serta kepuasan hidup, namun juga paling baik apabila difahami sebagai suatu konstruk multidimensional yang terdiri atas sikap hidup individu yang berhubungan dengna dimensi kesejahteraan psikologis itu sendiri, yang meliputi mampu merealisaikan potensi diri secara berkesinambungan, maVmpu memulai menjalin hubungan yang hangat dan akrap dengan orang lain, mempunyai kemandirian terhadap tekanan sosial, mampu menerima diri sendiri dengan apa adanya, merasa hidup yang dijalaninya memiliki arti, serta memiliki kemampuan untuk melakukan kontrol terhadap lingkunga eksternalnya.

Kesejahteraan psikologis menurut Hauser, Spinger dan Pudrovska (Prabowo, 2016) sebagai kesejahteraan psikologis yang dimiliki oleh individu yang menfokuskan pada upaya untuk merealisaikan dirinya (self-realization), pernyataan diri (self-expressiveness) serta aktualisasi diri (selfactualization).

Hurlock (Snyder dan Lopez) mendefinisikan kesejahteraan psikologis agak berbeda dengan yang lainnya. Menurut Hurlock, kesejahteraan psikologis merupakan suatu kebutuhan yang diperlukan untuk memenuhi tiga macam kebahagian, yaitu: penerimaan (acceptance), kasih sayang (affection), dan pencapaian (achievement).

Kesejahteraan psikologis menurut Ryff (2014) dapat dipengaruhi oleh dua factor, yaitu :

a. Faktor internal

1) Usia, Pengelompokan kesejahteraan psikologis berdasarkan usia, dibedakan dalam tiga kelompok, yaitu dewasa awal, dewasa tengah atau paruh baya, serta yang terakhir adalah dewasa akhir atau lansia. Pada kelompok tersebut, lebih dikhususkan pada dimensi penguasaan terhadap lingkungan, dimensi pertumbuhan diri, kemudian dimensi tujuan hidup, dan yang terakhir adalah dimensi otonomi. Pada dimensi penguasaan terhadap lingkungan individu mengalami peningkatan kemampuan, sejalan dengan bertambahnya usia. Dengan semakin bertambahnya usia individu, maka individu akan lebih mengetahui keadaan yang terbaik bagi dirinya. Hal ini berakibat individu akan semakin mampu mengatur lingkungannya sehingga menjadi yang terbaik sesuai dengan keadaan dirinya. Dibandingkan usia dewasa muda, individu usia menengah memiliki tingkat kesejahteraan psikologis yang lebih tinggi dalam dimensi penguasaan lingkungan dan dimensi otonomi. Tingkat kesejahteraan psikologis pada individu yang berada pada tahap dewasa akhir terlihat lebih rendah dalam dimensi keterarahan hidup dan dimensi pertumbuhan pribadi.

2) Jenis Kelamin, Secara umum tidak ada perbedaan tingkat kesejahteraan psikologis laki - laki dan perempuan, namun demikian perempuan, pada dimensi hubungan positif, kesejahteraan psikologisnya lebih tinggi bila dibandingkan dengan orang lain. Kelima dimensi lainnya tidak menunjukkan perbedaan yang signifikan antara pria dan wanita. Tingkat kesejahteraan 
112

psikologis lebih baik pada pria maupun wanita yang berpendidikan serta mempunyai pekerjaan yang baik.

3) Kepribadian, dimensi - dimensi dalam kesejahteraan psikologis memiliki hubungan yang erat dengan tipe kepribadian manusia. Hasil penelitian terdahulu menunjukkan bahwa:

a) Individu dengan tipe kepribadian extraversion memiliki skor yang tinggi pada dimensi penguasaan lingkungan, penerimaan diri, dan keterarahan hidup, demikian juga pada dimensi hubungan positif dengan orang lain.

b) Individu dengan tipe kepribadian conscientiousness, extraversion memperoleh skor yang tinggi pada dimensi penguasaan lingkungan, penerimaan diri, dan keterarahan hidup.

c) Individu yang memiliki tipe kepribadian low neurotisism dan extraversion memiliki yang skor tinggi pada dimensi penguasaan lingkungan, keterarahan hidup, dan penerimaan diri, serta dimensi otonomi.

d) Individu dengan tipe kepribadian openness to experience memperoleh skor yang tinggi dalam dimensi pertumbuhan pribadi.

e) Dimensi hubungan positif dengan orang lain didapatkan skor yang tinggi pada individu yang memiliki tipe kepribadian agreeableness.

b. Faktor eksternal

1) Status sosial ekonomi. Hasil penelitian menunjukkan bahwa, individu yang berasal dari kelompok berpendidikan tinggi, memperoleh skor yang tinggi pada dimensi tujuan hidup dan pertumbuhan pribadi, dibandingkan dengan kelompok yang berpendidikan rendah. Individu yang memiliki status pekerjaan yang tinggi ternyata tingkat kesejahteraan psikologis juga tinggi. Status pekerjaan yang tinggi disetai dengan tingkat pendidikan yang tinggi memberikan ketahanan yang bail dalam menghadapi stress kerja, tantangan serta kesulitan hidup, sebaliknya dengan tingkat pendidikan yang rendah disertai dengan status pekerjaan yang rendah pula, dapat menimbulkan kerentanan dan stress kerja yang pada akhirnya akan mengakibatkan adanya gangguna kesejahteraan psikologis.

2) Budaya. Terdapat perbedaan kesejahteraan psikologis yang dirasakan, pada kebudayaan timur dan kebudayaan barat. Konteks kebudayaan barat yang lebih bersifat individualistic, menyebabkan skor yang tinggi pada dimensi yang lebih menekankan atau berorinetasi pada diri sendiri, seperti misalnya pada dimensi penerimaan diri dan juga dimensi otonomi. Kebudayaan timur lebih bersifat kolektif dan saling ketergantungan antar individu, sehingga dimensi yang berorientasi pada orang lain, seperti halnya dimensi hubungan positif dengan orang lain mendapatkan skor yang tinggi.

3) Religiusitas. Kesejahteraan psikologis individu sangat dipengaruhi oleh agama dan spiritualitas. Dalam konteks ini sangat berkaitan dengan transendensi pada semua persoalan kehidupan individu kepada Tuhannya. Individu dengan tingkat religius yang tinggi, maka individu tersebut akan lebih mampu memandang setiap peristiwa yang terjadi secara bermakna dan mensikap secara positif, sehingga hidup yang dirasakannya menjadi lebih bermakna, dan bisa bersikap baik dengan lingkungan, mampu merasakan kepuasan hidup dan tidak banyak mengalami kesepian dalam hidupnya.

4) Dukungan social, Dukungan sosial merupakan perasaan nyaman, penghargaan, perhatian dan juga bantuan yang dipersepsikan oleh individu, yang dirasakan diperoleh dari orang lain, untuk memberikan suatu dukungan pada individu pada saat menghadapi persoalan kehidupannya. 
Dukungan yang dirasakan bisa berasal dari berbagai sumber. Sumber dukungan ini bisa berasal dari keluarga, suami atau istri, teman dekat, rekan sekerja ataupun organisasi social yang diikuti oleh individu tersebut.

Rasa syukur adalah salah satu faktor yang mempengaruhi kesejahteraan psikologis karena rasa syukur merupakan salah satu ciri dari pribadi yang selalu berfikir positif, yang kemudian dipresentasikan dalam perilaku yang lebih positif. (Wood, Joseph, \& Maltby, 2009).

Rasa syukur merupakan salah satu bentuk dari ekspresi kebahagian yang dirasakan oleh seseorang dan berhubungan dengan well-being. Selain itu syukur juga merupakan salah satu dari bentuk perilaku dari emosi yang positif, dengan kata lain, syukur bertolak belakang dengan emosi yang negative, seperti misalnya cemas, marah, cemburu, serta bentuk emosi yang negative lainnya (Emmons, 2004). Lebih lanjut Emmons (2007), menyebutkan bahwa dengan bersyukur mampu menjadikan seseorang lebih baik, bisa menjadi lebih bijaksana dalam menghadapi setiap permasalahan, juga mampu menciptkan keharmonisan antara dirinya dengan lingkungan dan komunitasnya. Namun ketidakbersyukuran yang dimiliki oleh individu akan dapat merusak keharmonisan yang sudah tercipta sebelumnya. Ketidakbersyukuran menurut Emmons (2007) diumpakan sebagai suatu kejahatan, dimana orang yang selalu tidak bersyukur akan cenderung untuk tidak menyukai kebaikan dalam bentuk apapun yang diterimanya dari orang lain, serta memiliki pemikiran yang sempit dalam mensikapi kebaikan yang diterimanya dari orang lain. Individu yang tidak bersyukur akan selalu mensikapi kebaikan dari orang lain dengan sikap mencemooh, mencaci maki, bahkan dengan kecurigaan dan kemarahan. Oleh karenanya dengan selalu bersyukur dapat dijadikan sebagai dasar yang kuat untuk membantu orang lain, hal ini disebabkan adanya sense terhadap sesame individu untuk selalu berbuat kebaikan.

Schwarz (Emmons \& Shelton, 2010), mengatakan bahwa rasa tidak bersyukur akan memunculkan rasa kedengkian, selalu mengeluh, juga dapat memunculkan banyak ketimpangan pada diri individu. Orang yang tidak pandai bersyukur hanya menfokuskan diri pada apa yang tidak dimilikinya, serta selalu membandingkan apa yang dimilikinya dengan yang dimiliki oleh orang lain. Dengan kata lain, orang yang tidak pandai bersyukur akan menjadikan dirinya terasing dengan lingkungannya sendiri.

Badburn (1969) membagi kesejaheraan psikologis menjadi dua dimensi. Dimensi tersebut berupa pengaruh positif dan pengaruh negatif. Dimensi pengeruh positif yaitu berupa perasaan positif seperti kebahagiaan, sedangkan pengaruh negatif sebaliknya.

Ryff (2014) menyatakan bahwa individu dengan kesejahteraan psikologis yang baik, adalah individu yang mampu berfungsi positif secara psikologis. Individu dengan fungsi psikologis yang positif, tercermin dalam beberapa dimensi, yaitu :

a. Penerimaan Diri, merupakan bentuk sikap positif individu yang mampu menerima baik, buruk, kekuatan dan kekurangan diri serta memandang positif masa lalu. Ini berarti jika individu memiliki penerimaan diri yang baik maka tingkat kesejahteraan psikologisnya tinggi. Sebaliknya, jika seseorang memiliki penerimaan diri yang rendah makan akan memiliki sikap tidak puas dengan keadaan diri, serta menyesali apa yang telah terjadi di masa lalu.

b. Hubungan Positif dengan orang lain, merupakan hubungan interpersonal yang aktif dan hangat, saling mempercayai satu dengan yang lain dan peduli terhadap kesejahteraan orang disekitarmya, mampu membangun hubungan timbal balik dengan orang lain, memiliki sifat empati dan mampu menunjukkan afeksi dalam berinterkasi dengan lingkungan sosial dan memahami konsep memberi dan menerima. 
114

c. Memiliki Kemandirian, merupakan kemampuan individu dalam mengorganisasi diri, mampu mengatasi tekanan sosial, tindakan yang dilakukan sesuai dengan keyakinan yang dimiliki, mampu mengatur perilakunya dari dalam diri dan melakukan evaluasi diri dari standar pribadi, mengambil keputusannya sendiri tanpa adanya campur tangan orang lain.

d. Penguasaan lingkungan, sebagai kemampuan menguasai dan mengatur lingkungan yang sesuai dengan dirinya, memanfaatkan kesempatan dengan efektif, menciptakan konteks yang sesuai dengan nilai dan kebutuhan pribadi, dan dapat mengatur lingkungannya dan mengendalikan aktivitas di lingkungannya.

e. Tujuan Hidup,Tujuan hidup adalah suatu perasaan yang terarah menuju tujuan yang akan di capai dalam hidup, individu merasakan tujuan hidupnya dan dapat merasakan kebermaknaan kehidupannya baik di masa sekarang maupun masa yang telah dilaluinya, berkeyakinan akan berhasil mencapai tujuan hidupnya, dan mengambil sisi positif pada setiap pengalam-pengalaman hidupnya.

f. Pertumbuhan diri, merupakan dimensi perkembangan yang sifatnya berkesinambungan, mampu melihat individu sebagai pribadi yang selalu tumbah dan berkembang, bersedia terbuka dengan pengalaman baru yang diterima, mampu menerima potensi diri yang dimilikinya, serta menyadari bahwa dia memiliki potensi tersebut, serta mampu melihat adanya peningkatan yang terjadi dalam diri dari waktu ke waktu, mampu menyadari adanya perubahan dan peningkatan pada diri dan perilakunya. Individu juga mampu berubah menjadi pribadi yang bertambah wawasan, cara fikir dan pengetahuannya serta menggunakannya dengan lebih efektif.

Banyak faktor yang mempengaruhi kesejahteraan psikologis seseorang, diantaranya adalah jenis kelamin, usia, kepribadian, kecerdasan emosi, budaya, status sosial ekonomi dan rasa syukur (Wood, Joseph, \& Maltby, 2009).

Syukur secara bahasa Arab berasal dari kata syakara, yang memiliki arti pujian atas kebaikan, terpenuhinya sesuatu, dan menampakkan pada permukaan, yang dalam hal ini adalah dalam bentuk memberikan sebagian nikmat yang telah diterima kepada orang lain yang membutuhkannya (Syam, 2009). Bersyukur menurut istilah syara' merupakan suatu pengakuan dari manusia terhadap nikmat yang telah diberikan oleh Allah SWT disertai dengan ketundukan dan kepatuhan kepada Allah dan mempergunakan nikmat yang telah diterimanya tersebut sesuai dengan kehendak dan ketuntan dari Allah SWT. Imam Al-Qusyairi (Sucipto \& Firdaus, 2011), memberikan penjelasannya bahwa hakikat dari bersyukur adalah pengakuan hamba Allah terhadap nikmat yang telah diberikan oleh Allah dan rasa syukur tersebut dibuktikan kepada ketundukan kepada Allah.

Gratitude yang dari bahasa Inggris bermakna rasa syukur, sedangkan kata gratitude dalam bahasa Latin berasal dari kata gratia, yang mempunyai arti kebaikan hati, kelembutan, serta terimakasih. Kata gratia yang berakar dari bahasa Latin ini berkaitan dengan makna kedermawanan, kebaikan, pemberian, juga keindahan dari buhungan meneri dan menerima, atau bisa juga bermakna mendapatkan sesuatu tanpa adanya tujuan apapun. (Emmons \& Cullough, 2003). Rasa syukur adalah suatu perasaan terima kasih dan rasa senang atas respon penerimaan hadiah, hadiah itu memberikan manfaat bagi seseorang atau suatu kejadian yang memberikan kedamaian (Peterson dan Seligman dalam Ishak. 2013). Menurut (Wood, Joseph, \& Maltby, 2009) Rasa syukur adalah sebagai bentuk ciri pribadi yang berpikir positif, dan mempresentasikan hidup menjadi lebih positif.

Rasa syukur menurut Manzur (Sulistyarini, 2010) adalah membalas kenikmatan yang telah diterima dalam bentuk niat, yang kemudian diucapka secara lisan dan diwujudkan dalam bentuk 
perilaku. Individu harus menyampaikan rasa syukurnya dengan ucapan secara lesan dengan sepenuh ketaatan, dengan keyakinan penuh bahwa semua yang diterima adalah semata - mata pemberian dari Allah SWT. Kata syukur merupakan bentuk mubalaghah dari kata syukur yang merupakan salah satu nama Allah.

Dewanto, dkk (2015) memaparkan bahwa rasa syukur merupakan pembentuk respon kognitif, emosi, dan perilaku. Lebih lanjut dijelaskan bahwa rasa syukur sebagai konstruksi kognitif, ditandai dengan adanya pengakuan atas kemurahan dan kebaikan hati dari apa yang telah diterima, serta lebih mengarahkan diri pada hal positif yang dimiliki pada diri saat ini. Beda halnya dengan rasa syukur sebagai konstruksi kognitif, rasa syukur sebagai konstruksi emosi yaitu dicirikan dengan adanya kemampuan individu dalam membentuk respon emosi dalam menemukan makna atas peristiwa yang dialami, sehingga dimungkinkan berdampak pada hadirnya perasaan takjub, penghargaan, dan rasa terimakasih kepada Tuhan atas anugerah kehidupan yang dijalani. Terakhir, rasa syukur sebagai konstruksi perilaku dapat dilihat dari adanya tidakan balasan kepada orang lain atas apa yang telah diperoleh.

Al-Gahazali (Al-Bantanie, 2009), menjelaskan bahwa bersyukur terdiri dari tiga perkara, yaitu:

a. Mempunyai pengetahuan tentang nikmat, artinya bahwa segala nikmat yang diterima, serta kebaikan adalah berasal dari Allah dan Allah-lah yang memberikan kepada pengetahuan tersebut kepada orang-orang yang dikehendaki-Nya

b. Memiliki sikap jiwa yang tetap dan tidak berubah, sehingga hasil dari pengetahuan yang telah dimiliki tersebut menjadikannya selalu merasa senang, kemudian mencintai yang telah memberikan nikmat tersebut dengan bentuk kepatuhan kepada Allah

c. Menghindarkan diri dari perbuatan maksiat yang telah dilarang oleh Allah

Fizgerald (Emmons \&Mc Cullough, 2004), telah mengindetifikasikan bahwa rasa syukur tersebut memiliki tiga komponen, yaitu:

a. A Warm sense of apperctiation, merupakan penilaian dan pengharapan terhadap orang lain disertai kehangatan untuk seseorang atau kepada sesuatu, yang meliputi rasa cinta, dan kasih sayang

b. A sense of goodwell, mempunyai kehendak yang baik, yang ditujukan kepada orang lain ataupun sesuatu, yang meliputi keinginan, untuk bersedia memberikan bantuan kepada orang lain yang sedang kesusahan, keinginan untuk berbagi, keinginan untuk memberikan kebahagian kepada orang lain, dan lain sebagainya

c. A disposition to act. Kecenderungan untuk bertindak secara positif, dengan memberikan pengjargaan dan kehendak baik kepada orang lain, lingkungan sekitar dan juga kepada Tuhan. Yang tindakannya meliputi intensi memberikan pertolongan kepada orang lain, membalas kebaikan orang yang telah berbuat baik kepada kita, melakukan ibadah sesuai dengan keyakinan masing - masing

Smith (Snyder \& Lopes, 2002), agak berbeda dengan Fizgerald (Emmons \&Mc Cullough, 2004), dalam mengidentifikasikan komponen dari bersyukur,yaitu:

a. A motivationally relavant outcame, adanya dorongan untuk menjalankan tindakan yang sesuai, atau adanya timbal balik atas perilaku atau pemberian yang diterima okeh individu tersebut

b. A motivationally congruent or desirable for the person, adanya suatu keinginan untuk melakukan atau membalas tindakan yang sama kepada orang lain yang sudah memberikan suatu penghargaan kepada orang tersebut, yang tindakan tersebut sesuai dengan yang diinginkan atau disukainya, 
116

dengan kata lain dapat diartikan dengan adanya keinginan untuk membuat seseorang yang telah memberikan penghargaan atau kebaikan tersebut menjadi senang

c. Credited to the efforts of another, Adanya rasa menghargai kepada orang lain, ata usaha yang sudah dilakukan.

Watkins, Wood, Stone \& Kolts (Ernawati I. , 2014) menjelaskan aspek- aspek dalam rasa syukur yang terdiri dari 3 poin yaitu:

a. Keberlimpahan (sense of abundance), ialah perasaan mendapat keberlimpahan hidup yaitu tidak akan merasa standar hidupnya menurun.

b. Apresiasi sederhana (simple appreciation), ialah rasa terimakasih terhadap hal- hal yang sepele yaitu cenderung untuk bersyukur dikarenakan mendapatkan kenikmatan atau kebaikan yang sederhana yang sifatnya non social, dalam kehidupan sehari - harinya.

c. Apresiasi yang diberikan kepada orang lain (appreciation of others) merupakan rasa terimakasih yang diberikan kepada orang lain, yaitu pemberian apresiasi dari individu kepada pihak lain yang telah memberikan kontribusi pada kesejahteraan hidupnya.

Steindl-Rast (Putra \& Satria, 2014) mengemukakan bahwa rasa syukur terdiri dalam dua aspek yaitu thankful dan grateful.

a. Thankful merupakan pola perilaku berterimakasih dari individu yang ditujukan kepada seseorang ataupun pihak lain, dalam hal ini objek syukurnya diarahkan kepada manusia atau individu yang telah memberikan kontribusi dalam kehidupannya.

b. Grateful, merupakan rasa terimakasih pada apa yang telah diterima, juga bisa bermakna respon penuh dari individu pada suatu yang dimilikinya, meskipun kepemilikan tersebut tersirat atau bersumber dari suatu hal diluar diri manusia seperti Tuhan, alam, dan kosmos.

Ibnu Qudamah (Al-bantanie, 2010), menjelaskan bahwa syukur, dilakukan berdasarkan tiga unsur, yaitu:

a. Bersykur dengan hati, yang tercermin dengan munculnya rasa puas, yang kemudian mendatangkan rasa senang, gembira, dan mengakui terhadap nikmat yang telah diterimanya tersebut adalah semata dari Allah

b. Bersyukur dengan lisan, melalui ucapan, yang tercermin dalam ucapan pujian terhadap Allah SWT

c. Bersyukur dengan perbuatan, diwujudka dengan perbuatan yang nyata, yaitu dengan cara mentaati segala yang diperintahkan oleh Allah serta menjauhi segala larangan Allah, dengan selalu bersujud syukur.

Rasa syukur merupakan sebuah bentuk emosi atau perasaan, yang kemudian berkembang menjadi suatu sikap, sifat moral yang baik, kebiasaan, sifat kepribadian, dan akhirnya akan mempengaruhi seseorang menanggapi atau bereaksi terhadap sesuatu atau situasi. Rasa syukur adalah perasaan terimakasih atas berkah yang telah diterima dan fokus terhadap hal positif di dalam dirinya saat ini. Sebagai konstruksi emosi, rasa syukur adalah mengubah respon emosi pada suatu peristiwa sehingga menjadi lebih bermakna (McCullough, Emmons, \& Tsang, 2004). Emosi syukur melibatkan perasaan takjub, terima kasih, penghargaan dan kebahagiaan atas anugerah dan kehidupan yang dijalani. Rasa syukur sebagai konstruksi perilaku yaitu melakukan tindakan balasan kepada orang lain atas manfaat dan anugerah yang telah diterima. Objek dari rasa syukur adalah Tuhan, orang lain, alam, dan lainnya (Wood, Emmons \& McCullough, 2004)

Kekuatan positif yang didapatkan oleh individu yang paling banyak memberikan keuntungan bagi individu itu sendiri, serta yang berkaitan dengan kesejahteraan psikologis adalah rasa syukur. 
Berdasarkan hasil penelitian Wood, Joseph, \& Maltby (2009) Rasa syukur secara signifikan berkorelasi dengan kesejahteraan psikologis. Rasa syukur berkaitan dengan positive coping, fungsi sosial dan memiliki efek unik dan sebab-akibat pada kesejahteraan positif dan hubungan sosial. Syukur sangat efektif dalam meningkatkan kesejahteraanseperti membangun sumber daya psikologis, sosial, dan spiritual (Emmons \& Cullough, 2003). Seseorang yang semakin banyak bersyukur, kesejahteraan psikologisnya akan semakin tinggi, karena individu tersebut akan mempunyai penilaian kognitif dan afektif yang positif terhadap kehidupannya, sebaliknya individu yang jarang bersyukur, maka akan mengalami gangguan kesejahteraan psikologis, sehingga kurang mampu melakukan penilaian kognitif dan afektif terhadap hidup yang dijalaninya.

Hipotesis yang diajukan dalam penelitian adalah Ada hubungan positif antara rasa syukur dengan Kesejahteraan psikologis pada guru honorer SD di UPT Disdikpora Kecamatan Pecangaan Kabupaten Jepara.

\section{METODE}

Penelitian ini merupakan penelitian kuantitatif korelasional, dengan dua variable, yaitu variable rasa syukur sebagai variable bebas dan kesejahteraan psikologis sebagai variable tergantungnya. Populasi yang digunakan dalam penelitian ini adalah guru honorer sekolah dasar di Kecamatan Pecangaan Kabupaten Jepara yang berjumlah 126 . Subjek dalam penelitian ini diambil dengan menggunakan tehnik insidental sampling yang merupakan teknik penentuan sampel berdasarkan individu atau subjek yang ditemui secara kebetulan yaitu siapa saja yang kebetulan bertemu dengan peneliti dan sesuai dengan kriteria yang telah ditentukan, maka dapat digunakan sebagai sampel (Sugiyono, 2014), dan diperoleh subjek sebanyak 63 orang.

Skala kesejahteraan psikologis dan skala skala rasa syukur digunakan untuk mengumpulkan data dalam penelitian ini. Skala kesejahteraan psikologis dibuat berdasarkan aspek kesejahteraan psikologis (Ryff, 2014) yang meliputi : penerimaan diri, hubungan positif dengan orang lain, memiliki kemandirian, penguasaan lingkungan, tujuan hidup, dan pertumbuhan diri; sedangkan skala rasa syukur dibuatkan didasarkan pada tiga aspek dari Watkins yaitu : keberlimpahan (sense of abundance), apresiasi sederhana (simple appreciation), dan apresiasi terhadap orang lain (appreciation of others).

\section{DISKUSI}

\section{Pengembangan alat ukur}

Skala kesejahteraan psikologis, dengan aspek yang terdiri dari penerimaan diri, hubungan positif dengan orang lain, memiliki kemandirian, penguasaan lingkungan, tujuan hidup, dan pertumbuhan diri, yang terdiri dari 40 item, dengan pernyataan favorable dan unfavorable. dengan daya beda berkisar antara 0,316-0,691 dengan koefisien, alpha Cronbach sebesar 0,931; sedangkan skala rasa syukur terdiri dari tiga aspek yaitu: keberlimpahan (sense of abundance), apresiasi sederhana (simple appreciation), dan apresiasi terhadap orang lain (appreciation of others) terdiri dari 37 item, dengan daya beda item berkisar antara 0,323-0,786 dengan koefisien alpha Cronbach sebesar 0,943.

\section{Pembahasan}

Tujuan dari penelitian ini adalah untuk menguji apakah terdapat hubungan antara rasa syukur dengan kesejahteraan psikologis pada guru honorer sekolah dasar (SD) di UPT Disdikpora Kecamatan 
118

Pecangaan Kabupaten Jepara. Hasil uji hipotesis pada penelitian ini menunjukkan nilai korelasi yang diperoleh $r_{x y}=0,744$ dengan taraf signifikansi $p=0,000$ (pada $p<0,01$ ). Hasil tersebut menunjukkan bahwa terdapat hubungan yang signifikan antara rasa syukur dengan kesejahteraan psikologis pada guru honorer sekolah dasar (SD) di UPT Disdikpora Kecamatan Pecangaan Kabupaten Jepara. Artinya semakin tinggi rasa syukur guru honorer, maka semakin tinggi pula kesejahteraan psikologis guru honorer tersebut. Sebaliknya, jika semakin rendah rasa syukur guru honorer, maka semakin rendah pula rasa syukur guru honorer tersebut. Hasil ini menunjukkan bahwa hipotesis peneliti diterima.

Hasil penelitian ini sejalan dengan penelitian yang dilakukan oleh Wood, dkk (2009), yang dilakukan terhadap 201 subjek, dengan model lima domain, dengan hasil bahwa rasa syukur sebagai hal yang sangat penting bagi kesejahteraan psikologis bagi individu.

Penelitian ini mendukung penelitian yang telah dilakukan oleh (Fivin \& Ishak, 2013) melakukan penelitian yang berjudul "Hubungan antara rasa syukur dengan kesejahteraan psikologis pada lanjut usia”. Penelitian ini memiliki subjek lanjut usia yang berjumlah 100 pada komunitas ARTAGA (Arek Taman Gayam). Hasil dari penelitian ini adalah ada hubungan yang positif dan signifikan antara rasa sukur dengan kesejahteraan psikologis pada lansia.

Kesejahteraan psikologis sebagai suatu kondisi seseorangyang dapat berfungsi secara positif. Individu dikatakan dapat berfungsi positif apabila dapat memenuhi keenam dimensi kesejahteraan psikologis. Kesejahteraan psikologis merupakan konsep teoritis yang meliputi kesehatan mental, kesejahteraan subjektif, dan kebahagiaan. Penekanan karakteristik positif dari pertumbuhan dan perkembangan individu merupakan konsep kesejahteraan psikologis modern. Kesejahteraan psikologis merupakan pencapaian positif secara optimal pada setiap individu. Selain itu kesejahteraan psikologis sebagai kombinasi dari perasaan positif. Perasaan positif tersebut seperti kebahagiaan dan efektifitas individu dalam kehidupan sosial (Hamburger, 2009).

Kesejahteraan psikologis merupakan suatu hal yang berhubungan dengan pengalaman dan keadaan diri yang berfungsi optimal. Pandangan filsafat tentang kesejahteraan psikologis ada 2, pertama tujuan hidup manusia adalah mencapai kebahagiaan. Pandangan tersebut merupakan pandangan hedonic. Kedua, tujuan hidup manusia dalam pencapaian kebahagiaannya dengan cara mengaktualisasikan dirinya (Ryan \& Deci, 2001). Kesejahteraan psikologis juga dapat menjadikan gambaran mengenai level tertinggi dari fungsi individu sebagai manusia dan apa yang diidamidamkannya sebagai mahluk yang memiliki tujuan dan akan berjuang untuk hidupnya (Synder, 2002).

Rasa syukur adalah salah satu faktor yang mempengaruhi kesejahteraan psikologis karena rasa syukur sebagai bentuk kepribadian seseorang yang berfikir positif dan mempresentasikan menjadi lebih positif (Wood, Joseph, \& Maltby, 2009). Wood mengemukakan bahwa rasa syukur memiliki hubungan positif dengan kepuasan hidup, gairah hidup dan kebahagiaan, sebaliknya rasa syukur memiliki hubungan negatif dengan perasaan negatif seperti kedengkian dan depresi yang berarti semakin tinggi rasa syukur maka semakin rendah perasaan dengki dan depresi. Kesulitan yang dialami pada guru honorer karena kurangnya tujuan hidup, kemandirian, pertumbuhan diri secara pribadi, kurangnya dukungan social, tidak ada hubungan positif dengan orang lain, dan kepercayaan diri sehingga mengakibatkan guru honorer tersebut sulit untuk mencapai kesejahteraan psikologis, tetapi jika seseorang merasa syukur maka diasumsikan orang tersebut memiliki kesejahteraan psikologis.

Hasil analisis data skala kesejahteraan psikologis menunjukkan bahwa kesejahteraan psikologis pada guru honorer tergolong tinggi. Hal ini dapat diketahui dari rentang skor subjek (berdasarkan mean empirik) berada dalam kategori tinggi yaitu 130.9841. Hasil analisis data tersebut berbeda 
dengan hasil wawancara peneliti dengan guru honorer. Studi pendahuluan yang dilakukan peneliti, berupa wawancara menunjukkan hasil bahwa kesejahteraan psikologis guru honorer kurang. Wawancara dilakukan hanya pada beberapa guru honorer jadi kurang menyeluruh. Subjek wawancara mengatakan bahwa subjek merasa gajinya sangat sedikit tidak cukup untuk memenuhi kebutuhan sehari-hari, kurang mendapatkan dukungan sosial karena banyak teman mencemooh gajinya sangat sedikit, ada juga yang menyarankan untuk mencari pekerjaan yang baru, dalam satu kantor juga tidak semua orang baik karena terkadang ada yang iri dengan pekerjaan teman atau ingin terlihat lebih baik didepan atasan sehingga menjatuhkan teman sendiri. Subjek yang diwawancarai hanya 3 orang sedangkan sampel penelitian 126 . Peneliti juga tidak menanyakan apakah subjek memiliki usaha atau pekerjaan lain selain menjadi guru honorer atau tidak. Hal inilah yang menjadi penyebab mengapa terdapat perbedaan hasil studi pendahuluan dengan hasil penelitian.

Hasil analisis data penelitian ini menunjukkan bahwa rasa syukur dengan kesejahteraan psikologis pada guru honorer sekolah dasar (SD) di UPT Disdikpora Kecamatan Pecangaan Kabupaten Jepara berada pada kategori tinggi. Hal tersebut berdasarkan mean empirik skor sampel kesejahteraan psikologis berada dalam kategorisasi tinggi yaitu 130.9841 dan mean empirik skor sampel rasa syukur juga berada dalam kategorisasi tinggi yaitu 124.9841.

\section{KESIMPULAN}

1. Ada hubungan positif yang signifikan antara rasa syukur dengan kesejahteraan psikologis pada guru honorer sekolah dasar (SD) di UPT Disdikpora Kecamatan Pecangaan Kabupaten Jepara

2. Rasa syukur memberikan sumbangan efektif sebesar $55,4 \%$ terhadap kesejahteraan psikologis guru honorer sekolah dasar (SD) di UPT Disdikpora Kecamatan Pecangaan Kabupaten Jepara

\section{SARAN}

1. Saran bagi guru honorer

Guru honorer diharapkan dapat mempertahankan rasa syukur yang sudah tinggi dengan cara bertanggung jawab terhadap apa yang telah dilakukan, mengerjakan tugas tepat waktu, dan bersyukur atas pendapatan yang didapat.

2. Saran bagi peneliti selanjutnya

Peneliti selanjutnya diharapkan dapat menambahkan jumlah sampel penelitian sehingga akan lebih representatif dan memperkaya hasil penelitian. Selain itu juga disarankan agar peneliti selanjutnya dapat meneliti faktor-faktor lain yang tidak diteliti dalam penelitian ini, yang diperkirakan dapat mempengaruhi kesejahteraan psikologis guru honorer. Faktor-faktor tersebut antara lain yaitu; usia, jenis kelamin, kepribadian, status sosial ekonomi, budaya, dukungan sosial, kompetensi pribadi, dan religiusitas.

\section{Daftar Pustaka}

Albantanie, S. (2010). Dahsyatnya syukur. Jakarta: Qultum Media. 
Asti Aisyah dan Rohmatun Chisol

120

Fivin, F., \& Ishak, J. S. (2013). Hubungan antara rasa syukur dengan kesejahteraan psikologis pada lanjut usia.

Emmons, R. A. (2007). Thanks: How the new science of gratitude can make you happier. Boston: Houghton Company.

Emmons, R. A., \& Mc Cullough, M. E. (2004). The psychology of gratitude. New York: Oxford University Press.

Emmons, R. A., \& Sheldon, E. (2010). Gratitude and the science of positive psychology. Handbook of positive psychology. New York: Oxford University Press.

Hamburger. (2009). Technology and psychological well-being.

McCullough, M. E., Emmons, R. A., \& Tsang, J. A. (2004). Gratitude in intermediate affective terrain: links of grateful moods to individual differences and daily emotional experience. Journal of Personality and Social Psychology , 86, 295-309.

Nugroho, F. E. (2016, Agustus 06). Cerita Rizma Guru Tegal Cantik Bertahan dengan Honor Rp 75 Ribu. Dipetik September 23, 2016, dari http://m.liputan6.com/regional/read2570525/ceritarizma-guru-tegal-cantik-bertahan-dengan-honor-rp-75-ribu

Prabowo. (2016). Kesejahteraan psikologis remaja di Sekolah. Jurnal Ilmiah Psikologi Terapan. Vol 04, No $02,246-260$.

Peterson, \& Seligman. (2004). Character strengths and virtues . New york : Oxvord University Press.

Putri, L. S. (2013). Hubungan antara religiusitas dengan kesejahteraan psikologis pada lansia muslim.

Ramadhani, T., Djunaidi, \& Sismiati, A. (2016). Kesejahteraan psikologis (psychological well-being) siswaa yang orang tuanya bercerai (Studi deskripstif yang dilakukan pada siswa di SMK Negri 26 Pembangunan Jakarta). Insight: Jurnal Bimbingan Konseling 5 (1), 108 - 115.

Ryan, R. M., \& Deci, E. L. (2001). On happiness and human potentials. A Review of Research on Hedonic and Eudaionic Well-Being , Annual Review of Psycholgy, 141-166.

Ryff, C. D. (1989). Journal of Personality and Social Psychology. Happiness is Everything, or is it? Exploration on the meaning of psychology well-being , $52: 1069$ - 1081.

Snyder, C. R., \& Lopes, S. J. (2002). Handbook of positive psychology. New York: Oxfrd University Press.

Sucipto, H., \& Firdaus, A. I. (2011). Dahsyatnya syukur dan sabar. Jakarta: Best Media.

Sugiyono. (2009). Metode Penelitian Kuantitatif, Kualitatif, dan R \& D. Bandung: Alfabeta.

Suyanto, \& Abbas. (2005). Wajah dan Dinamika Pendidikan Anak Bangsa. Yogyakarta: Adicita Karya Nusa.

Syam, Y. (2009). Sabar dan syukur bikin hidup lebih bahagia. Jogjakarta: Mutiara Media. 
Synder, C. J. (2002). Health Psychology. New York: Oxford University Press.

Tanujaya, W. (2014). Hubungan Kepuasan Kerja dengan Kesejahteraan Psikologis pada Karyawan Cleaner ( Studi pada Karyawan Cleaner yang meneria gaji tidak sesuai standart UMP di PT.Sinergi Integra Services, Jakarta.

Wood, A. M., Joseph, S., \& Maltby, J. (2009). Gratitude predicts psychological well-being above the big five facets. Journal of Personality and Individual Different , 46, 443-447. 
Asti Aisyah dan Rohmatun Chisol

122 